\title{
Features of fascin expression in the small intestine of rats exposed to processed Eucheuma seaweed
}

\begin{abstract}
Anton Tkachenko
Biochemistry Department, Kharkiv National Medical University, Kharkiv, Ukraine
\end{abstract}

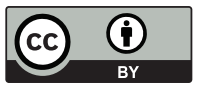

This work is licensed under a

Creative Commons Attribution 4.0 International License

Received: 2019-12-26

Accepted: 2020-01-10

UDC: 616.341-092.18-092.9:577.114.4

\section{J Clin Med Kaz 2019; 4(54):40-44}

Corresponding Author: Anton Tkachenko, PhD,

Associate Professor, Biochemistry Department, Kharkiv

National Medical University, Nauky av. 4, 61022

Kharkiv, Ukraine. Tel.: +380 5010945 54;

fax: +380 577004132

E-mail: antontkachenko555@gmail.com

\section{Abstract}

This study focuses on the assessment of fascin expression in the small intestinal tissue of rats orally administered a food additive E407a (processed Eucheuma seaweed), which is widely used to improve the texture of food products. The issue of its safety is under debate nowadays. Small intestinal expression of fascin, an actin-bundling cytoskeletal protein involved in the formation of filopodia and microspikes, was evaluated immunohistochemically in 9 rats exposed to $140 \mathrm{mg}$ of E407a per $\mathrm{kg}$ of weight daily during two weeks and 8 control animals. Fascin was found to be upregulated both in the lamina propria and epithelia of the small intestine in rats administered processed Eucheuma seaweed compared with the control group. Thus, oral consumption of E407a is associated with overexpression of fascin in the small intestine of rats.

Key words: carrageenan, food additive, fascin, intestinal inflammation

\section{ЖАРТЫЛАЙ ТАЗАРТЫЛҒАН ЕUСНЕЧМА БАЛДЫРЛАРДЫ ҚОЛДАНУ ФОНЫНА ҚАРСЫ ЕГЕУКҰЙРЫҚТЫҢ ТІК ІШЕГІНДЕГІ ФАСЦИН ЭКСПРЕССИЯСЫНЫН ЕРЕКШЕЛІКТЕРІ}

\section{А.С. Ткаченко}

Биохимия кафедрасы, Харьков ұлттық медицина университеті, Харьков, Украина

\section{ТҰЖЫРЫМДАМА}

Бұл жұмыс тамақ өнімдерінің құрылымын жақсарту үшін кеңінен қолданылатын Е407а (өңделген Еuсhеuта балдырлары) тағамдық қоспасын ауызбен қабылдау аясында егеуқұйрықтардың тік ішегіндегі фассин ақуызының экспрессия деңгейін бағалауға арналған. Бұл қоспаның қауіпсіздік мәселесі қызу талқылануда. Фасциннің - филоподияның пайда болуына қатысатын цитоскелет ақуызының экспрессиясын 2 апта бойы тәулігіне 1 кг дене салмағына 140 мг Е407а егілген 9 егеуқұйрықтан және 8 бақыланатын жануарлардан иммуногистохимиялық әдіспен бағалады.

Фасциннің экспрессия деңгейі бақылау тобымен салыстырғанда, өңделген эвакуациялық балдырлармен емделген егеуқұйрықтардағы шырышты қабықтың ішкі қабығында да, тік ішектің эпителийінде де жоғары екендігі анықталды. Осылайша, Е407а препаратын ауызбен қабылдау егеуқұйрықтардың тік ішегіндегі фасиннің шамадан тыс эксперссияланумен байланысты.

Негізгі сөздер: каррагинан, тағамдық қоспалар, фасцин, ішек қабынуы

\section{ОСОБЕННОСТИ ЭКСПРЕССИИ ФАСЦИНА В ТОНКОМ КИШЕЧНИКЕ КРЫС НА ФОНЕ УПОТРЕБЛЕНИЯ ПОЛУОЧИЩЕННЫХ ВОДОРОСЛЕЙ ЕUСНЕUМА}

А.С. Ткаченко

Кафедра биохимии, Харьковский национальный медицинский университет, Харьков, Украина

\section{PEЗЮME}

Данная работа посвящена оценке уровня экспрессии белка фасцина в тонком кишечнике крыс на фоне перорального употребления пищевой добавки E407a (обработанные водоросли Eucheuma), которая широко используется для улучшения текстуры пищевых продуктов. Вопрос безопасности данной добавки активно обсуждается. Экспрессию фасцина - белка цитоскелета, участвующего в образовании филоподий - оценивали иммуногистохимическим методом у 9 крыс, которым вводили 140 мг Е407а на кг веса в сутки на протяжении 2 недель, и у 8 контрольных животных. Было обнаружено, что уровень экспрессии фасцина выше как в собственной пластинке слизистой оболочки, так и в эпителии тонкого кишечника у крыс, которым вводили обработанные водоросли Еuсhеuта, по сравнению с контрольной группой.

Таким образом, пероральное употребление Е407а связано с гиперэкспрессией фасцина в тонком кишечнике крыс.

Ключевые слова: каррагинан, пищевая добавка, фрасцин, воспаление кишечника 


\section{Introduction}

Carrageenans (CGNs) are hydrophilic, sulfated polysaccharides composed of galactose derivatives linked with $\alpha-1,4$ and $\beta$-1,3-glycosidic bonds [1]. CGNs are known as food additives E407 (food-grade or refined) and E407a (semi-refined CGN also known as processed Eucheuma seaweed (PES). Compared to PES, refined CGN contains small amounts of acid insoluble matter (AIM, primarily algal cellulose), while the content of AIM in E407a varies from $8 \%$ to $15 \%$ [2]. CGNs have found extensive application in food industry, since they show gelling, stabilizing, protein-suspending, emulsifying and thickening properties [3]. CGNs are categorized into several types, including $\lambda, \kappa, 1, \varepsilon, \mu$, depending on the sulfation degree, which can reach $35 \%$ [4].

The share of CGN market is the fourth largest among hydrocolloid additives and approximately 70,000 tones of this food additive is produced annually [2]. In addition to its role of a food additive, CGNs are added to meat as a cheap non-meat ingredient. This is considered an illegal food fraud [5].

According to different estimates, the daily intake of CGNs in Western diet may reach up to $7.7 \mathrm{~g}$ and it has been increasing since the appearance of the first data in 1970s [6,7]. However, the average consumption of CGN in industrialized countries is estimated to reach $250 \mathrm{mg}$ per day [8,9].

According to numerous studies, CGN consumption poses serious health-related risks [4,10]. Food additives E407 and E407a have been demonstrated to promote intestinal inflammation in laboratory animals [4, 10-14]. Furthermore, CGNs have been shown to induce generation of reactive oxygen species (ROS) and pro-inflammatory cytokines, including in colonocytes [15-18]. However, the findings outlined above are challenged and refuted by the studies in which it is stated that CGNs are non-toxic compounds, which have neither ROS-generating nor pro-inflammatory properties $[19,20]$. Such multidirectional conclusions in evaluating the toxicity of CGNs may be due to confusion in terms, since polysachharides with different structures and molecular weights may be referred to as CGNs in research papers: food-grade CGN (200-800 kDa), degraded CGN (20-40 kDa), and poligeenan $(10-20 \mathrm{kDa})$. Food-grade CGN is officially recognized safe by major international regulatory authorities, including the Food and Drug Administration, while degraded CGN and poligeenan are prohibited to be used in food industry due to their well characterized toxic effects [19].

To add some insight to the mechanisms by which foodgrade CGN-containing food additives may promote intestinal inflammation, we evaluated the influence of PES on the expression of fascin protein. Fascin is a cytoskeletal protein, which is responsible for the formation of cell protrusions, filopodia, and microspikes providing cell motility. Its expression is reported to be limited to cells of mesenchymal origin, and this protein is not expressed in epithelial cells under normal circumstances [21]. There is strong evidence that fascin may induce epithelial-mesenchymal transition (EMT), which is a process of losing epithelial features by cells and gaining properties of mesenchymal cells, inter alia, the ability to move [22, 23]. It is important to emphasize that EMT plays a significant role in intestinal inflammation [24], making promising the assessment of fascin expression for evaluating the impact of E407a on the intestine.

The aim of this study was to evaluate features of fascin expression in the small intestine of rats orally exposed to a common food additive E407a during two weeks.

\section{Material and methods}

\section{Study design}

WAG rats weighing 160-190 g were used in this study. Group 1 consisted of 9 animals orally administered a water solution of E407a containing $140 \mathrm{mg}$ of PES per $\mathrm{kg}$ of weight on a daily basis during a fortnight. Group 2 served as control and included 8 intact rats. The rats were maintained in standard laboratory conditions. Access to food was provided ad libitum. The animals of both groups were sacrificed with the subsequent collection of fragments of small intestine for immunostaining.

This study was approved by the local Ethics and Bioethics Committee at Kharkiv National Medical University (Kharkiv, Ukraine).

All the experimental procedures were carried out following the guidelines of EU Directive 2010/63/EU on the protection of animals used for scientific purposes, which is based on the Council of Europe Convection for the Protection of Vertebrate Animals used for Experimental and other Scientific Purposes (ETS123).

\section{Immunostaining}

Tissue samples were washed with ice-cold saline after their collection. They were fixed in formalin solution for 24 hours. Then samples were dehydrated in alcohol of ascending grades and cleared in xylene. Four- $\mu$ m-thick sections from paraffinembedded small intestine samples were immunostained using mouse monoclonal antibodies to fascin. Ultra Vision Quanto Detection System HPR DAB Chromogen manufactured by Thermo Fischer Scientific (UK) was used visualization.

According to the staining protocol, the microslides were incubated with the primary anti-fascin antibodies and secondary horseradish peroxidase-conjugated antibodies. The appearance of brown coloration was considered a marker of positive staining, since 3,3'-diaminobenzidine (DAB) was used for visualization.

\section{Results}

We evaluated the expression of fascin in the small intestinal mucosa of a total of nine rats consumed a common food additive PES whose major ingredient is kappa-carrageenan during a fortnight and eight control animals. In the control samples, fascin expression was limited to the lamina propria. The small intestinal epithelia of rats not exposed to PES showed no signs of fascin staining (Figure 1).

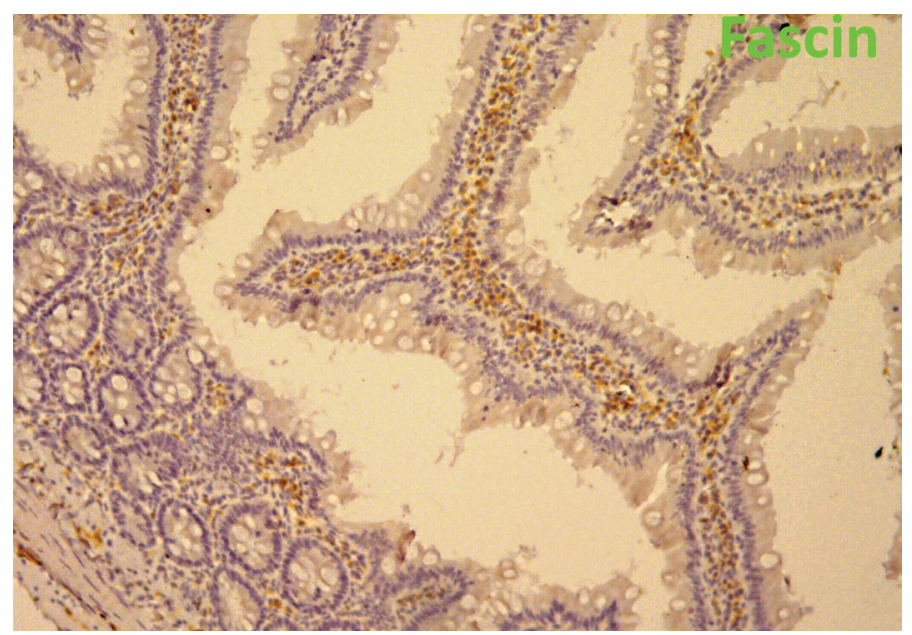

Figure 1 - Representative microphotograph of fascin staining in the small intestine of a rat from the control group. Fascin expression is not found in the epithelial cells, while moderate staining in observed in the lamina propria. 100x. 


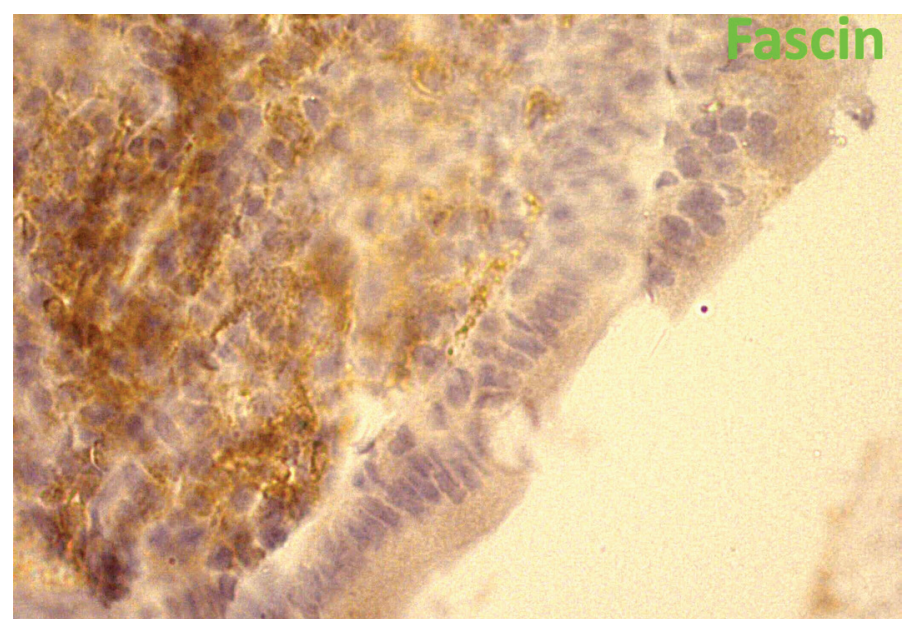

Figure 2 - Fascin expression in the small intestine of a rat orally exposed to E407a during 2 weeks. Fascin is upregulated in the stroma. Furthermore, fascin staining can be noticed in the small intestinal epithelial lining. 400x.

However, fascin-positive cells, including presumably fibroblasts, some types of leukocytes and endothelia of stromal microvasculature, were observed in the lamina propria of intact small intestine (Figure 1). Thus, fascin immunostaining was detected in cells of mesenchymal origin in the control group and was absent in apparently normal epithelial cells.

The pattern of fascin expression in the small intestine of rats administered E407a differed from samples of the control animals. Some areas of epithelia demonstrated no fascin staining. In other regions, staining varied from low to high. Moderate fascin staining was mainly found in the epithelial lining, which was not observed in controls (Figures 2, 3). It is worth emphasizing that fascin expression was stronger in areas with the damaged villi in comparison with the regions less affected by the inflammation. Fragments of desquamated villous epithelia with fascin overexpression could be even noticed in the intestinal lumen (Figure 3). In the intestinal stroma, a significant increase in fascin immunoreactivity was determined in animals after exposure to E407a (Figures 2, 3). The intense positivity was observed in regions where villous epithelial lining was damaged.

\section{Discussion}

In several studies it has been shown that fascin is virtually absent in the intestinal epithelial lining in normal conditions $[25,26]$. This fact was corroborated by our findings. However, inflammatory processes in the intestine result in upregulation of this protein. It is of huge importance to mention that fascin overexpression in inflammatory bowel disease (IBD) is associated with regions of intense repair and regeneration, since fascin is involved in repairing gaps in the damaged epithelial barrier [25]. The pattern of fascin expression observed in this study confirms this hypothesis, since its extremely strong expression was found in the damaged areas with the desquamated epithelia located in the lumen of the small intestine. Thus, fascin upregulation in the epithelial cells of rats exposed to E407a can be considered a response to the $\mathrm{CGN}$-induced tissue damage.

It is believed that fascin overexpression is a subject to an inflammation-mediated regulation. It has been reported that inflammation-related cytokines such as tumor necrosis factoralpha (TNF- $\alpha$ ), IL-1 $\beta$ and transforming growth factor-beta (TGF- $\beta$ ) may upregulate fascin $[27,28]$. Thus, it can be assumed

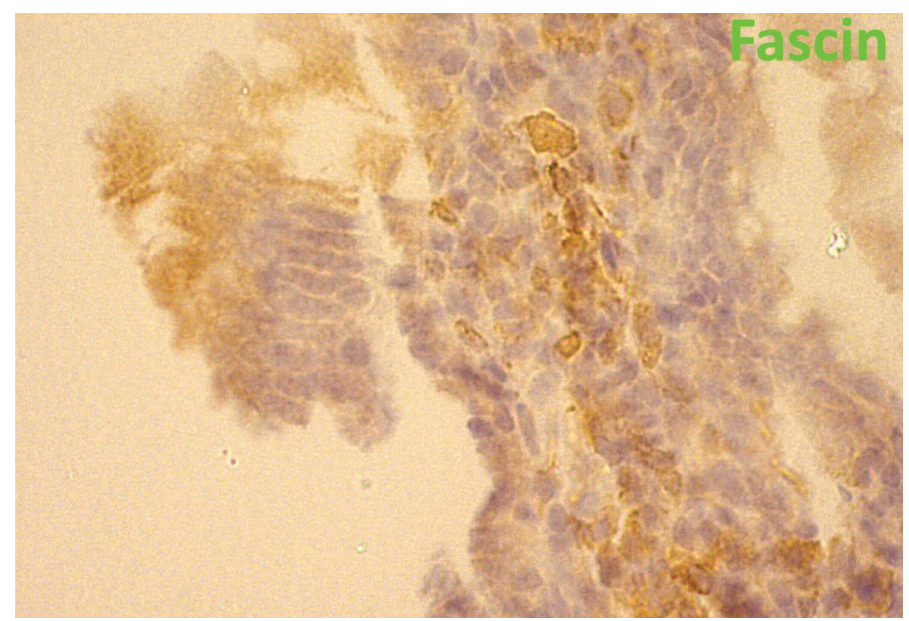

Figure 3 - Fascin immunostaining in the small intestine of an animal administered a common food additive E407a. A higher fascin expression is observed in the lamina propria. Fragments of desquamated epithelia with strong fascin expression are seen in the lumen. 400x.

that E407a-induced tissue damage and destruction resulted in the development of inflammation and subsequent overexpression of fascin in the most damaged areas due to the pro-inflammatory microenvironment.

Furthermore, strong expression of fascin in rats exposed to PES may promote EMT, since fascin is known to be involved in EMT and fascin knockdown suppresses this process in experiments [23]. It is worth noting that after exposure to E407a some intestinal epithelial cells lose the ability to produce E-cadherin and start expressing vimentin (unpublished data), which is typical for EMT. In particular, these key events in EMT, namely loss of E-cadherin, a cell-cell adhesion molecule that provides normal connection of cells in the epithelial layer, and expression of vimentin, an intermediate filament protein involved in cell motility, are mediated by Snail1, a member of Snail transcription factors [29]. Fascin is known to be actinbundling protein required for the formation of actin-based cell protrusions. It is important to mention that fascin is overexpressed in various tumors providing their motility and invasion [21, 30]. Fascin expression in epithelial cells changes significantly their morphology, including the appearance of lamellopodia and induction of an increase amount of microvilli on the apical surface of cells. Such fascin-induced morphological alterations provide epithelial cells with the ability to move [31,32]. Thus, our findings of fascin upregulation observed primarily in the regions of damaged epithelia under the influence of CGN-containing food additive E407a indicate that its overexpression may have reparative functions. In agreement with previous studies, we can assume that the fascin-expressing epithelial cells after the intake of E407a acquire the ability to move and may cover areas of deepithelialized villi to try to maintain the integrity of epithelial barrier and prevent the flow of luminal bacteria deeper in the intestinal mucosal layer.

We believe that a higher amount of fascin-expressing cells in the stroma of small intestine collected from E407aconsuming animals can be due to an increase in the number of motile fibroblasts and dendritic cells that can express this protein [33]. To some degree, EMT may contribute to an increase in the number of fibroblasts in rats exposed to E407a, since this process has been identified to provide fibroblasts involved in the emergence of intestinal fibrosis in experimental models of IBD in mice. In particular, Flier et al reported that approximately 
$30 \%$ of fibroblasts in 2,4,6-trinitrobenzene sulfonic acid (TNBS)-induced experimental colitis are former epitheliocytes undergone EMT [34]. This hypothesis was supported by other studies indicating that EMT can be considered one of the major contributors to the formation of activated fibroblasts $[35,36]$.

Our findings of fascin overexpression both in the epithelial layer and stroma of the small intestine of rats exposed to E407a suggest that CGN may upregulate fascin. However, it is now clear how the induction occurs. We can speculate that fascin overexpression develops in response to CGN-induced intestinal inflammation.

\section{Conclusion}

Oral administration of a $\kappa$-carrageenan-containing common food additive E407a during two weeks results in damage to the small intestine and the appearance of compensatory fascin expression in small intestinal epithelial cells to repair the regions affected and fascin upregulation in the lamina propria.

Acknowledgment: The author expresses profound gratitude to Prof. Galina Gubina-Vakulyck who greatly assisted the research.

Disclosures: There is no conflict of interest for all authors.

\section{References}

1. David S, Shani Levi C, Fahoum L, Ungar Y, Meyron-Holtz EG, Shpigelman, A, et al. Revisiting the carrageenan controversy: do we really understand the digestive fate and safety of carrageenan in our foods? Food Funct. 2018; 9(3):1344-1352. https://doi.org/10.1039/ C7FO01721A

2. Hotchkiss S, Brooks M, Campbell R, Philp K, Trius A. The use of carrageenan in food. In: Pereira L (ed) Carrageenans: sources and extraction methods, molecular structure, bioactive properties and health effects. 1st edn. Nova Science Publications Inc., New York. 2016; 1-293

3. Campo VL, Kawano DF, da Silva DB, Carvalho I. Carrageenans: Biological properties, chemical modifications and structural analysis-A review. Carbohydrate Polymers. 2009; 77(2):167-180. https://doi.org/10.1016/j.carbpol.2009.01.020

4. Necas J, Bartosikova L. Carrageenan: a review. Veterinarni Medicina. 2013; 58:187-205.https://doi.org/10.17221/6758-VETMED

5. Fiorino GM, Garino C, Arlorio M, Logrieco AF, Losito I, Monaci L. Overview on untargeted methods to combat food frauds: a focus on fishery products. Journal of Food Quality. 2018; 1581746:13. https://doi.org/10.1155/2018/1581746

6. 6. Shah ZC, Huffman FG. Current availability and consumption of carrageenan-containing foods. Ecol. Food Nutr. 2003; 42(6):357-371. https://doi.org/10.1080/03670240390265175

7. Nicklin S, Miller K. Intestinal uptake and immunological effects of carrageenan-current concepts. Food Addit. Contam. 1989; 6(4):425436. https://doi.org/10.1080/02652038909373801

8. Bhattacharyya S, Shumard T, Xie H, Dodda A, Varady KA, Feferman L, et al. A randomized trial of the effects of the no-carrageenan diet on ulcerative colitis disease activity. Nutr Healthy Aging. 2017; 4(2):181-192. https://doi.org/10.3233/NHA-170023

9. Tobacman JK. The common food additive carrageenan and the alpha-gal epitope. J Allergy Clin Immunol. 2015; 136(6):1708-1709. https://doi.org/10.1016/j.jaci.2015.08.048

10. Tobacman JK. Review of harmful gastrointestinal effects of carrageenan in animal experiments. Environ Health Perspect. 2001; 109(10):983-994. https://doi.org/10.1289/ehp.01109983

11. Tkachenko AS, Onishchenko AI, Gorbach TV, Gubina-Vakulyck GI. O-6-methylguanine-DNA methyltransferase (MGMT) overexpression in small intestinal mucosa in experimental carrageenan-induced enteritis. Malay. J. Biochem. Mol. Biol. 2018; 21(3):7780 .

12. Tkachenko A, Marakushyn D, Kalashnyk I, Korniyenko Y, Onishchenko A, Gorbach T, et al. A study of enterocyte membranes during activation of apoptotic processes in chronic carrageenan-induced gastroenterocolitis. Med Glas (Zenica). 2018; 15(2):87-92. https://doi. org/10.17392/946-18

13. Tkachenko AS, Marakushyn DI, Rezunenko YK, Onishchenko AI, Nakonechna OA, Posokhov YO. A study of erythrocyte membranes in carrageenan-induced gastroenterocolitis by method of fluorescent probes. HVM Bioflux. 2018; 10(2):37-41.

14. Gubina-Vakyulyk GI, Gorbach TV, Tkachenko AS, Tkachenko MO. Damage and regeneration of small intestinal enterocytes under the influence of carrageenan induces chronic enteritis. Comparative Clinical Pathology. 2015; 24(6):1473-1477. https://doi.org/10.1007/ s00580-015-2102-3

15. Sokolova EV, Menzorova NI, Davydova VN, Kuz'mich AS, Kravchenko AO, Mishchenko NP, et al. Effects of carrageenans on biological properties of Echinochrome. Mar Drugs. 2018; 16(11):419.https://doi.org/10.3390/md16110419

16. Bhattacharyya S, Dudeja PK, Tobacman JK. Carrageenan-induced NFאB activation depends on distinct pathways mediated by reactive oxygen species and Hsp27 or by Bcl10. Biochimica et Biophysica Acta-General Subjects. 2008; 1780(7-8):973-982. https://doi. org/10.1016/j.bbagen.2008.03.019

17. Bhattacharyya S, Gill R, Chen ML, Zhang F, Linhardt RJ, Dudeja PK, et al. Toll-like receptor 4 mediates induction of the Bcl10NFkappaB-interleukin-8 inflammatory pathway by carrageenan in human intestinal epithelial cells. J Biol Chem. 2008; 283(16):105508. https://doi.org/10.1074/jbc.M708833200

18. Borthakur A, Bhattacharyya S, Dudeja PK, Tobacman JK. Carrageenan induces interleukin-8 production through distinct Bcl10 pathway in normal human colonic epithelial cells. The American Journal of Physiology-Gastrointestinal and Liver Physiology. 2007; 292(3):G829-G838. https://doi.org/10.1152/ajpgi.00380.2006

19. McKim JM, Willoughby JA Sr, Blakemore WR, Weiner ML. Clarifying the confusion between poligeenan, degraded carrageenan, and carrageenan: A review of the chemistry, nomenclature, and in vivo toxicology by the oral route. Crit Rev Food Sci Nutr. 2019; 59(19):3054-3073. https://doi.org/10.1080/10408398.2018.1481822

20. McKim JM Jr, Baas H, Rice GP, Willoughby JA Sr, Weiner ML, Blakemore W. Effects of carrageenan on cell permeability, cytotoxicity, and cytokine gene expression in human intestinal and hepatic cell lines. Food Chem Toxicol. 2016; 96:1-10. https://doi.org/10.1016/j. fct.2016.07.006

21. Machesky LM, Li A. Fascin: invasive filopodia promoting metastasis. Commun Integr Biol. 2010; 3(3):263-270. https://doi.org/10.4161/ cib.3.3.11556 
22. Li J, Zhang S, Pei M, Wu L, Liu Y, Li H, et al. FSCN1 promotes epithelial-mesenchymal transition through increasing Snaill in ovarian cancer cells. Cell Physiol Biochem. 2018; 49(5):1766-1777. https://doi.org/10.1159/000493622

23. Mao X, Duan X, Jiang B. Fascin induces epithelial-mesenchymal transition of cholangiocarcinoma cells by regulating Wnt/ $\beta$-Catenin signaling. Med Sci Monit. 2016; 22:3479-3485.https://doi.org/10.12659/MSM.897258

24. Lovisa S, Genovese G, Danese S. Role of epithelial-to-mesenchymal transition in inflammatory bowel disease. J Crohns Colitis. 2019; 13(5):659-668. https://doi.org/10.1093/ecco-jcc/jjy201

25. Qualtrough D, Smallwood K, Littlejohns D, Pignatelli M. The actin-bundling protein fascin is overexpressed in inflammatory bowel disease and may be important in tissue repair. BMC Gastroenterol. 2011; 11:14. https://doi.org/10.1186/1471-230X-11-14

26. Qualtrough D, Singh K, Banu N, Paraskeva C, Pignatelli M. The actin bundling protein fascin is overexpressed in colorectal adenomas and promotes motility in adenoma cells in vitro. Br J Cancer. 2009; 101:1124-1129. https://doi.org/10.1038/sj.bjc.6605286

27. Zhang X, Cho IH, Park JH, Lee MK, Hwang YS. Fascin is involved in cancer cell invasion and is regulated by stromal factors. Oncol Rep. 2019; 41(1):465-474. https://doi.org/10.3892/or.2018.6847

28. Onodera M, Zen Y, Harada K, Sato Y, Ikeda H, Itatsu K, et al. Fascin is involved in tumor necrosis factor-alpha-dependent production of MMP9 in cholangiocarcinoma. Lab Invest. 2009; 89(11):1261-74. https://doi.org/10.1038/labinvest.2009.89

29. Chen L, Yao Y, Sun L, Zhou J, Miao M, Luo S, et al. Snail driving alternative splicing of CD44 by ESRP1 enhances invasion and migration in epithelial ovarian cancer. Cell Physiol Biochem. 2017; 43:2489-2504. https://doi.org/10.1159/000484458

30. Adams JC. Roles of fascin in cell adhesion and motility. Curr Opin Cell Biol. 2004; 16(5):590-6. https://doi.org/10.1016/j.ceb.2004.07.009

31. Khurana S, George SP. The role of actin bundling proteins in the assembly of filopodia in epithelial cells. Cell Adh Migr. 2011; 5(5):409420. https://doi.org/10.4161/cam.5.5.17644

32. Yamashiro S, Yamakita Y, Ono S, Matsumura F. Fascin, an actin-bundling protein, induces membrane protrusions and increases cell motility of epithelial cells. Mol Biol Cell. 1998; 9(5):993-1006. https://doi.org/10.1091/mbc.9.5.993

33. Jayo A, Parsons M, Adams JC. A novel Rho-dependent pathway that drives interaction of fascin-1 with p-Lin-11/Isl-1/Mec-3 kinase (LIMK) $1 / 2$ to promote fascin-1/actin binding and filopodia stability. BMC Biol. 2012; 10:72. https://doi.org/10.1186/1741-7007-10-72

34. Flier SN, Tanjore H, Kokkotou EG, Sugimoto H, Zeisberg M, Kalluri R. Identification of epithelial to mesenchymal transition as a novel source of fibroblasts in intestinal fibrosis. J Biol Chem. 2010; 285(26):20202-12. https://doi.org/10.1074/jbc.M110.102012

35. Scharl M, Huber N, Lang S, Fürst A, Jehle E, Rogler G. Hallmarks of epithelial to mesenchymal transition are detectable in Crohn's disease associated intestinal fibrosis. Clin Transl Med. 2015; 4:1. https://doi.org/10.1186/s40169-015-0046-5

36. Zavadil J, Bottinger EP. TGF-beta and epithelial-to-mesenchymal transitions. Oncogene. 2005; 24:5764-74. https://doi.org/10.1038/ sj.onc. 1208927

How to cite this article: Anton Tkachenko. Features of fascin expression in the small intestine of rats exposed to processed Eucheuma seaweed. J Clin Med Kaz. 2019; 4(54):40-44 